\title{
Paideusis
}

\section{Training Teachers in Logical Reasoning}

\section{Michael Schleifer}

Volume 4, Number 1, 1990

URI: https://id.erudit.org/iderudit/1073390ar

DOI: https://doi.org/10.7202/1073390ar

See table of contents

Publisher(s)

Canadian Philosophy of Education Society

ISSN

0838-4517 (print)

1916-0348 (digital)

Explore this journal

Cite this article

Schleifer, M. (1990). Training Teachers in Logical Reasoning. Paideusis, 4(1),

14-18. https://doi.org/10.7202/1073390ar

(c) Michael Schleifer, 1990

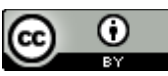

This document is protected by copyright law. Use of the services of Erudit (including reproduction) is subject to its terms and conditions, which can be viewed online.

https://apropos.erudit.org/en/users/policy-on-use/
This article is disseminated and preserved by Érudit.

Érudit is a non-profit inter-university consortium of the Université de Montréal, Université Laval, and the Université du Québec à Montréal. Its mission is to promote and disseminate research.

https://www.erudit.org/en/ 


\title{
Training Teachers in Logical Reasoning
}

\author{
Michael Schleifer \\ Université du Québec à Montréal
}

There are different views about what should, and should not, be attempted in courses in foundations of education. Recently, one specific strand of this dispute has concerned the introduction of logic for teachers in training. At least two Canadian philosophers have recently stated that they would advise anything but logic in foundations courses in education faculties. ${ }^{1}$ I take the opposite view, namely, that one should strive to introduce logic with its application to areas of moral, scientific, and common-sense reasoning.

I wish to support two intertwined theses about logic and teachers. The first thesis is of its very nature pessimistic: one will have only limited success introducing logic to teachers, only some improvement in reasoning for the great majority, and greater success (but never total success) with two or three per group of thirty. I believe that this limited success is built-in to the process since most students of education faculties have had no background in thinking critically. I shall return to this point by way of examples comparing younger children with adults on reasoning tasks.

The second thesis - the more optimistic one - states simply that progress is possible insofar as specific stratagems are employed. Several examples from my own teaching experience shall be used to illustrate this. Specifically, the student-teachers must be made to feel emotively involved.

The two theses are intertwined, and mutually dependent. Having lowered my expectations over the years about the level of success one can obtain (thesis 1), I have also resorted (somewhat shamefully at first) to the tricks and stratagems I think necessary to obtain even limited success (thesis 2). I shall illustrate both the thesis concerning limitations, as well as disclose some of the stratagems by way of two examples: one from logical reasoning about morality and common sense, the second from reasoning about science.

In our courses in epistemology, we have been inspired primarily by the work of Piaget. Although theories of instruction connected with other views on learning (Skinner, Rogers, Bruner) are more directly related to teaching, and although Piaget, it is said, cared little about teachers, ${ }^{2}$ our inspiration remains obstinately Piagetian. By this, I mean his emphasis on the rational justifications given by children (and adults) for their views. We have attempted to adopt this Piagetian focus in our psychological studies on moral reasoning. ${ }^{3}$ Naturally enough, this preoccupation with reasoning and justification was transposed to the courses we designed for teachers in training. In discussing moral and social issues, for example, we wished to emphasize the importance of arguments, or good reasons, and not simply the presentation of an accepted traditional view or unsupported opinion. Whether discussing moral education, or the teaching of history or the rules of language, the emphasis was always on thinking critically, evaluating arguments, concentrating more on proper form and rigour rather than on content.

With this orientation in mind, the introduction of some general considerations of reasoning was inevitable. Consider the following argument of a child. 


\section{Example I}

If I am bad, I am punished.

That boy was hit by his mother.

He must have been bad ... 4

One way to understand the difficulties the child has in dealing with authority and gaining a more mature grasp of the concepts of moral responsibility and punishment is in terms of a cognitive incapacity. Put simply, the reasoning in the above example is fallacious. It is of the form, if $p$, then $q, q$, therefore $p$. One ingredient in moral education, then is for the teacher to be aware of this kind of improper reasoning. The goal is by no means necessarily to attempt to correct it directly, or even to discuss it. Various educational approaches to the issue are possible. 5 Whatever the approach, however, an awareness of the problems of reasoning would seem indispensable.

On the first attempt to introduce the above example of improper reasoning, it was evident that practically none of the student-teachers understood the lesson. It seems that the great majority of student-teachers (like most of their university and college classmates) are no further advanced than the children. In fact, they commit exactly the same fallacies in logical reasoning as do children. ${ }^{6}$ University students are no more masters of this domain than are children at the elementary level. For the past few years, in working with the programme "Philosophy for Children," " I have become impressed by how effectively large numbers of young children can begin to grasp elementary principles about conditional reasoning, and avoid the fallacies surrounding them. It is of interest that one of the strategies which is effective in helping the reasoning of children is to change the content. Consider the next example:

\section{Example II}

If there is a snowstorm, the school is closed.

The school is closed.

Therefore, what can what conclude?

Most children (and adults) will conclude that there was a snowstorm (the same fallacy as in Example I). Although the content is neither abstract (no mathematical symbols) nor complex (as the moral example above), children have considerable difficulty with this. However, making use of their imagination and creativity, and using fictional contents often has a dramatic effect in simulating better logical reasoning.

Our university students cannot cope any better with these examples. About one-third can spot the fallacy; no more than five percent can reason cogently about an entire series of these problems. Furthermore, the stratagems which are effective with children, such as fictional and imaginary contexts, do not work with young adults. The one technique I have found efficacious to a degree is to use examples which are more involving emotively. Some research has shown ${ }^{8}$ the usefulness of using a content which involves lifestyles more directly related to adolescents. 


\section{Examples III}

If I drink beer, I am over 21 .

I am 19.

Therefore what can I conclude?

\section{Example IV}

If I drink beer, I am over 21 .

If I am 22.

Therefore what can I conclude?

The correct answers are that: I can conclude that I do not drink beer if I am 19 (Example III); if I am 22 (example IV), I cannot conclude anything with certainty. This reasoning is very difficult for most students, but there is more ${ }^{9}$ success with these examples than with equivalent ones concerning a snowstorm (Example III).

In my classes, I have found the following example works well.

\section{Example V}

If I obtain an A,I must do all the work.

I do all the work.

What can I conclude?

The correct answer - that one cannot conclude whether the student has obtained an $\mathrm{A}$ or a C - is, once again, very difficult for most students. However, there is more involvement and interest because of the nature of the example (everyone has some concern with marks, alas). I found the success-rate can be increased even more by fabricating a scenario. I have pretended, for example, that there is a committee hearing about a protest by a student against a professor. Within this drama, I introduced the argument about the work and the " $A$ ". I get almost complete attention, and find that there is an increased awareness in the importance of reasoning and detecting fallacies. The success, however, remains partial since approximately ten percent of students can show mastery of all the forms of logical reasoning. The remaining ninety percent have at least had their attention drawn to an area which until then had escaped them entirely.

My second example concerning logical reasoning is culled from my experience with teachers and the science curriculum. In Quebec, there has been quite an extensive introductory natural science programme for at the elementary level. One chapter introduces the planetary system, another gravity, and so on. In an attempt to put the (Piagetian) focus on reasoning, I asked my studentteachers how they would justify correcting a student who said, for example, that the sun revolved around the earth, rather than the "official" version which they were to teach. My hope, of course, was to bring out a discussion about relative scientific paradigms, epistemological criteria of acceptance of propositions, and other philosophical considerations raised by Kuhn, Polanyi, and others. I have long since given up hoping to reach consideration of these lofty levels. I now am content if at least a minority of students are willing to acknowledge that the child's point of view is worthy of consideration, and that some defence of the "official" view is necessary. All too many students (in 1989, as in 1975 when I 
began teaching these courses) are content to say "That's the official program." It matters little to most of them that the child's view may be well reasoned and logically coherent. Part of my task is to demonstrate that both points of view the child's old-fashioned Aristotelian one and the official Copernican one - are capable of being justified. From this step, it is still a long way to considering the criteria for justification.

In order to help make student-teachers more aware of the issue, I again resorted to the kind of ploy described above. A scenario is invented is which some parents who belong to a society whose beliefs include that the sun revolves around the earth make a complaint. It is their children who have been "corrected" by the teacher whose job is now on the line. Accused of intolerance and indoctrination, I invoke the unions, various rights groups, and some religious orders. With all this dramatic fiction as background, it is somewhat easier to get student-teachers to consider reasoning about science, and to attempt a justification of their point of view. A minority of about ten percent begin to consider the foundations of science, and the relevant epistemological criteria. The majority, at least, finds itself emotively involved in the issue.

The justification for the ploys is their usefulness in arousing studentteachers' interest and focusing the discussion. With the more ongoing content, there is a greater chance that one can achieve one's main aim, which is to foster reasoning. These tricks seem to work, and that is perhaps sufficient justification for them. There is, in addition, evidence from the studies mentioned above, which lend credence to my teaching experience. One could perhaps also add one other explanation in terms of Piaget's theory of cognitive development. According to Piaget, the kind of knowledge connected with logical competence involves not just a notion that something is the case, but rather a conviction that it must be the case - a conviction of necessity. One ingredient in the development of this higher stage of development is cognitive conflict. Furthermore, the efficacy of cognitive conflict is necessarily connected to an affective component. Having a problem truly "felt" by a subject is indispensable to mastery, structural change, and cognitive development. 


\section{Notes}

${ }^{1}$ The first of these was Ralph $\mathrm{H}$. Johnson who took this position in his paper, "Critical Thinking," presented at the Symposium at the Annual Meeting of the Canadian Society for Studies in Education, Windsor, June 1988. Johnson specifically advocated no logic for teachers in training, and criticized the point of view I defended at the panel, which does emphasize the importance of logic at all levels. The second "logic-basher" was Michael Jackson at a symposium on Philosophy of Education and Teacher-Training at the Annual Meetings of C.S.S.E., at Laval University, Quebec, June 1989.

${ }^{2}$ P.E. Bryant, "Piaget, Teachers, and Psychologists," Oxford Review of Education, 10(3), 1984.

${ }^{3} \mathrm{M}$. Schleifer and T.R. Shultz, "Towards a refinement of attribution concepts," in M. Hewstone, F.D. Fincham, and J. Jaspars (eds.), Attribution theory and research: Conceptual, developmental, and social dimensions (New York: Academic Press, 1983), 37-62; M. Schleifer, T.R. Shultz, and K. Wright, "Assignment of moral responsibility and punishment," Child Development, (57), 1986, 177-184.

${ }^{4}$ M. Schleifer, "Le conflit cognitif chez Piaget: Une interpretation," dans N. Bednarz et C. Garnier (eds.), Construction des savoirs: Obstacles et conflits (Montreal: Agence d'Arc, 1988); M. Schleifer, and V. Douglas, "Moral judgments, behavior, and cognitive style in young children," Canadian Journal of Behavioral Science, 5(2), 1973, 133-144.

${ }^{5}$ Discussed in Schleifer, op. cit.

${ }^{6} \mathrm{H}$. Markovits, M. Schleifer, and L. Fortier, "The development of elementary deductive reasoning," Developmental Psychology, 25(5), 1989, 787-793; H. Markovits, E. Bialystok, and M. Schleifer, "Wason's task: Formal or post-formal reasoning," Post-formal Reasoning (abstracts) (Cambridge: Harvard University Press, (April 7) 1987).

${ }^{7}$ A. Caron, M. Schleifer, G. Potvin, and P. Lebuis, La philosophie dans le curriculum scolaire (Montreal: Agence d'Arc, in press).

${ }^{8}$ W.F. Overton, S.L. Ward, I.A. Noveck, O.P. O'Brien, J. Black, "Form and Content in the Development of Deductive Reasoning," Developmental Psychology, 23(1), 1987, 22-30.

${ }^{9}$ See Schleifer, op. cit., for a fuller discussion. 